University of Nebraska - Lincoln

DigitalCommons@University of Nebraska - Lincoln

Temporal and Spatial Variation in Solar Radiation and PhotoEnhanced Toxicity Risks of Spilled Oil in Prince William Sound, Alaska, USA

\author{
Mace G. Barron \\ U.S. Environmental Protection Agency, barron.mace@epa.gov \\ Deborah Vivian \\ U.S. Environmental Protection Agency \\ Susan H. Yee \\ U.S. Environmental Protection Agency \\ Steve A. Diamond \\ U.S. Environmental Protection Agency
}

Follow this and additional works at: https://digitalcommons.unl.edu/usepapapers

Barron, Mace G.; Vivian, Deborah; Yee, Susan H.; and Diamond, Steve A., "Temporal and Spatial Variation in Solar Radiation and Photo-Enhanced Toxicity Risks of Spilled Oil in Prince William Sound, Alaska, USA" (2008). U.S. Environmental Protection Agency Papers. 115.

https://digitalcommons.unl.edu/usepapapers/115

This Article is brought to you for free and open access by the U.S. Environmental Protection Agency at DigitalCommons@University of Nebraska - Lincoln. It has been accepted for inclusion in U.S. Environmental Protection Agency Papers by an authorized administrator of DigitalCommons@University of Nebraska - Lincoln. 


\title{
TEMPORAL AND SPATIAL VARIATION IN SOLAR RADIATION AND PHOTO- ENHANCED TOXICITY RISKS OF SPILLED OIL IN PRINCE WILLIAM SOUND, ALASKA, USA
}

\author{
Mace G. Barron, $* \dagger$ Deborah Vivian, $\dagger$ Susan H. Yee, $\dagger$ and Steve A. Diamond \\ †Gulf Ecology Division, U.S. Environmental Protection Agency, Gulf Breeze, Florida 32561 \\ \$Mid-Continent Ecology Division, U.S. Environmental Protection Agency, Duluth, Minnesota 55804
}

(Received 22 May 2007; Accepted 19 September 2007)

\begin{abstract}
Solar irradiance $\left(\mathrm{W} / \mathrm{m}^{2}\right)$ and downwelling diffuse attenuation coefficients $\left(K_{\mathrm{d}} ; 1 / \mathrm{m}\right)$ were determined in several locations in Prince William Sound (AK, USA) between April 2003 and December 2005 to assess temporal and spatial variation in solar radiation and the risks of photo-enhanced toxicity from spilled oil. Weekly irradiance measurements of surface visible light, ultraviolet B (UVB), and ultraviolet A (UVA) radiation in Valdez (AK, USA) followed expected trends of maximum solar irradiance at each summer solstice and minimum values at each winter solstice. Variation from weekly maximum expected surface irradiances was attributed to large variations in environmental conditions over the 142-week monitoring period. Season and proximity to glacial meltwater were significant determinants of $K_{\mathrm{d}}$, with $1 \%$ attenuation depths ranging from 0.4 to $15 \mathrm{~m}$ (UVB and UVA) and from 0.5 to $28 \mathrm{~m}$ (visible light). The probability of photo-enhanced toxicity risks estimated from UVA dosimetry decreased with increasing water depth, with higher risks during spring and summer and lower risks during fall and winter. These results demonstrate substantial temporal and spatial variation in solar radiation in Prince William Sound and the potential for significant season- and locationspecific photo-enhanced toxicity risks from spilled oil.
\end{abstract}

Keywords-Phototoxicity Oil Risk Ultraviolet radiation

\section{INTRODUCTION}

The ultraviolet regions of solar radiation can substantially increase the toxicity and risks of polycyclic aromatic hydrocarbons (PAHs), heterocycles, and other chemicals with specific structural features at irradiances occurring in aquatic environments [1]. Photo-enhanced toxicity occurs through either photochemical modification or through generation of reactive oxygen species after bioaccumulation of phototoxic chemicals and has been demonstrated primarily in small translucent organisms, such as early life stages of shellfish, crustaceans, and fish [2]. These organisms may lack pigment and have an epidermis of only a few layers, allowing ultraviolet radiation (UV) to penetrate deeply [3]. The UV can then activate the bioaccumulated compounds, resulting in the generation of toxic intermediates, such as oxygen radicals, and cause rapid tissue damage and death in excess of what would occur in the absence of UV [4-6]. Exposure to UV has been demonstrated to increase the toxicity of both fresh and weathered crude oils and petroleum products to embryos and larvae of freshwater and marine invertebrates and fish [7-10]. Oil-plus-UV exposures can increase the toxicity of petroleum from twofold to greater than 100 times the toxicity of oil-only or UV-only exposures, but photo-enhanced toxicity is species and life-stage specific

* To whom correspondence may be addressed (barron.mace@epa.gov).

This manuscript is contribution 1300 of the Gulf Ecology Division of the U.S. Environmental Protection Agency (U.S. EPA) Office of Research and Development's National Health and Environmental Effects Research Laboratory. It has been reviewed by the U.S. EPA National Health and Environmental Effects Research Laboratory (Gulf Breeze, FL), but the information in this document does not necessarily reflect the views and policies of the U.S. EPA.

Published on the Web 11/5/2007.
[11]. Alaska North Slope crude oil (ANS) has been demonstrated to be phototoxic to both Pacific herring (Clupea pallasii) larvae and marine zooplankton under limited exposure to natural sunlight $[6,12]$. Recent research also has demonstrated that oil mixed with an oil-dispersing agent was more toxic in the presence of UV at levels present in aquatic environments [6]. The mechanism of ANS phototoxicity is through a process of initial bioaccumulation of specific PAHs and heterocyclic aromatics in early life stages of aquatic organisms that are relatively translucent to UV [6].

Barron and Ka'aihue [5] concluded that the potential for photo-enhanced toxicity existed in Prince William Sound (PWS; AK, USA) based on UV levels estimated from an atmospheric model, and they reported petroleum concentrations during the Exxon Valdez oil spill. To our knowledge, however, a quantitative assessment of photo-enhanced toxicity risks from spilled oil in PWS has never been reported, in part because solar radiation in PWS has received only limited spatial and temporal characterization [13]. In the present study, solar radiation monitoring was initiated in PWS to characterize solar radiation doses to aquatic organisms and test the hypothesis that phototoxicity would vary with season, depth, and location. This research addressed three specific objectives. The first was to determine temporal variability in surface solar radiation and ultraviolet A (UVA) dosimetry by performing weekly surface measurements in the city of Valdez (AK, USA). The second was to characterize the seasonal and spatial variation in the optical properties of the water column of PWS to allow extrapolation of irradiances and UVA water-column doses to other locations and times of year. The third was to perform a screening-level, probabilistic assessment of the ecological risks of photoenhanced toxicity of spilled oil in PWS using UVA toxicity benchmarks. Larval herring were used as the 


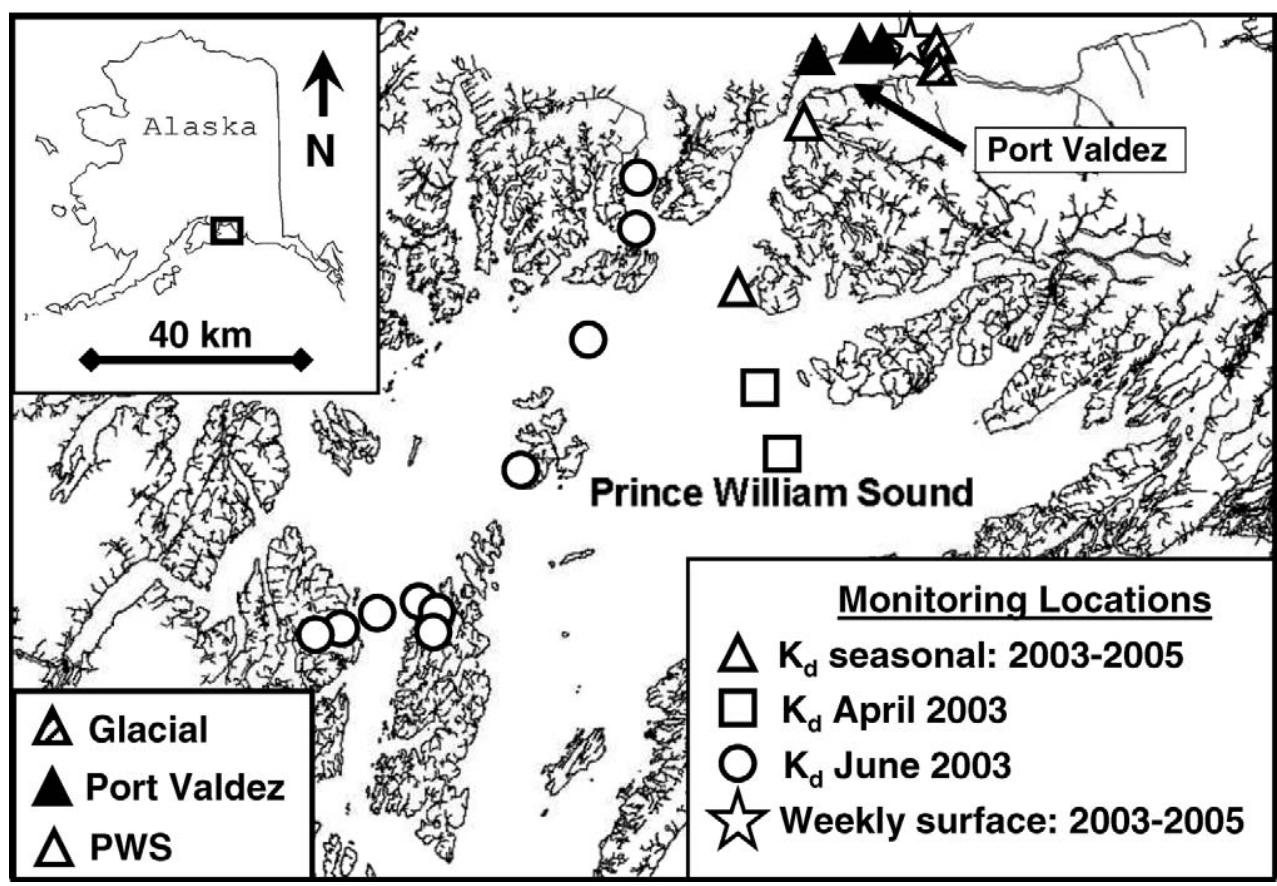

Fig. 1. Solar radiation monitoring locations in Port Valdez and Prince William Sound, Alaska, USA. Symbol shading denotes site classification used in Table 2 and statistical analyses. See Table 1 for latitude and longitude of sites.

ecological receptor in this screening-level risk assessment because of their known sensitivity to ANS phototoxicity and extensive pelagic distribution in PWS that encompassed the solar radiation monitoring sites used in the present study $[6,14,15]$. As noted by Stevenson [14], McGurk and Brown [15], and Norcross et al. [16], larval herring are pelagic planktivores feeding on zooplankton in the upper regions of the photic zone, typically within $2 \mathrm{~km}$ of shore. Larval herring are not free-swimming and are carried rapidly by tidal currents away from intertidal areas into open-water bays [14-16]. Zooplankton are another potential ecological receptor that have been demonstrated to be sensitive to ANS phototoxicity, whereas other species and life stages, such as salmon, may not be at risk from photo-enhanced toxicity of spilled oil $[11,12]$.

\section{MATERIALS AND METHODS}

\section{Study overview}

As detailed below, the present study was designed to characterize the effects of spatial and temporal variation of solar radiation in PWS on phototoxicity risks estimated from UVA dosimetry and a UVA-based toxicity benchmark for larval herring. Visible light and ultraviolet B (UVB) also were measured to assess variation in solar irradiance and attenuation and because UVB likely influences photo-enhanced toxicity risks [6]. Monitoring locations were selected to represent the diversity of marine environments in PWS, and locations more than $100 \mathrm{~m}$ from shore were selected to represent a general area rather than only nearshore, localized conditions. Additionally, offshore areas were representative of the habitat, water clarity, and water quality of the pelagic ecological receptors for this screening ecological risk assessment. Pacific herring were selected as the ecological receptor in this screening-level risk assessment because of high sensitivity of larvae to the photo-enhanced toxicity of ANS and their life history as intertidal spawners and pelagic planktivores [6,14-16]. Doses of UVA were calculated from measured ground-surface irradiances and downwelling diffuse attenuation coefficients $\left(K_{\mathrm{d}}\right)$ determined over a 2.5-year period. The $K_{\mathrm{d}}$ values were grouped into three site classifications within PWS: Locations affected by glacial streams (glacial), Port Valdez (AK, USA) locations away from direct glacial impacts (Port Valdez), and open sea or bays of PWS outside Port Valdez (Fig. 1). Seasonal changes in $K_{\mathrm{d}}$ values were determined in relation to the spring phytoplankton bloom and temporal changes in glacial influences to characterize the effect of UV attenuation on the probability of phototoxicity risks.

\section{Measurement and modeling of surface solar radiation}

Weekly measurements of downwelling solar radiation were performed at the ground surface in the City of Valdez (AK, USA; $61^{\circ} 07.37^{\prime} \mathrm{N}, 146^{\circ} 21.22^{\prime} \mathrm{W}$ ) at approximately solar noon between April 2003 and December 2005 (Fig. 1). The irradiance $\left(\mathrm{W} / \mathrm{m}^{2}\right)$ of total UVB (280-320 nm), UVA (320-400 $\mathrm{nm})$, and visible light (400-700 nm) was measured with a Macam UV-203 broad wavelength radiometer (BWR; Macam Photometrics, Livingston, Scotland). The BWR was calibrated against standards traceable to the National Physical Laboratory and the British Standard Institution (Middlesex, UK).

Surface irradiance at solar noon also was estimated using an atmospheric model to allow comparisons between estimated maximum values and measured values affected by environmental conditions. Surface solar radiation in Port Valdez was estimated with the Santa Barbara Discrete Ordinate Radiative Transfer Module atmospheric radiative transfer model (SBDART) [17]. The SBDART is based on physical models that explain the plane-parallel radiative transfer of solar radiation, and it was run under default conditions for clouds and gas absorption, rural aerosol conditions, subarctic atmospheric profile, and surface conditions of sand or snow to estimate flux at sea level. 
Table 1. Routine solar radiation monitoring locations in Prince William Sound (PWS), Alaska, USA a,b

\begin{tabular}{lcccc}
\hline Site & Site classification & Approximate depth $(\mathrm{m})$ & Latitude & Longitude \\
\hline Bligh Reef & PWS & 210 & $\mathrm{~N} 60^{\circ} 48.138$ & $\mathrm{~W} 146^{\circ} 51.807$ \\
Outer Jack Bay & PWS & 183 & $\mathrm{~N} 61^{\circ} 02.444$ & $\mathrm{~W} 146^{\circ} 39.321$ \\
Shoup Bay & Port Valdez & 64 & $\mathrm{~N} 61^{\circ} 07.694$ & $\mathrm{~W} 146^{\circ} 35.242$ \\
Gold Creek & Port Valdez & 24 & $\mathrm{~N} 61^{\circ} 07.712$ & $\mathrm{~W} 146^{\circ} 28.757$ \\
Mineral Creek & Port Valdez & 24 & $\mathrm{~N} 61^{\circ} 07.495$ & $\mathrm{~W} 146^{\circ} 25.433$ \\
Glacial Stream & Glacial & 11 & $\mathrm{~N} 61^{\circ} 06.146$ & $\mathrm{~W} 146^{\circ} 17.010$ \\
Lowe River & Glacial & 11 & $\mathrm{~W} 146^{\circ} 17.565$ \\
\hline
\end{tabular}

a Monitoring locations greater than $100 \mathrm{~m}$ from shore were selected to represent water clarity in a general area rather than only localized conditions (all sites).

b Additional locations monitored in April and June 2003 (not listed). See Figure 1 and Barron and Barron [13].

\section{Water-column solar irradiance and water quality}

Seasonal measurements of downwelling solar irradiance was performed at multiple locations in Port Valdez and PWS between April 2003 and September 2005 (Table 1 and Fig. 1). Replicate profiles of solar radiation were performed at the surface and at three to five depths between 0.2 to $8 \mathrm{~m}$ with the BWR at each location listed in Table 2. Spring sampling dates in mid-April were selected to coincide with the approximate peak of the spring plankton bloom in PWS [18]. Summer monitoring was timed to coincide with the increase in fresh- water and glacial flour in Port Valdez and PWS that occurs each year. The summer monitoring also characterized UV and visible light irradiances during the period of the greatest day length and highest sun angle. Fall monitoring was timed to coincide with water conditions occurring before the onset of winter conditions and concurrent decrease in freshwater input and glacial flour. The fall monitoring also characterized UV and visible light during the period of decreasing day length and lower sun angle. Because of logistical issues, winter monitoring was only performed on January 5, 2005 (Table 2).

Table 2. Seasonal variation of diffuse attenuation coefficients $\left(K_{\mathrm{d}} ; \mathrm{m}^{-1}\right)$ for ultraviolet A (UVA), ultraviolet B (UVB) and visible solar radiation in Prince William Sound (PWS), Alaska, USA

\begin{tabular}{|c|c|c|c|c|c|}
\hline \multirow[b]{2}{*}{ Monitoring date } & \multicolumn{2}{|c|}{ Monitoring stations } & \multirow[b]{2}{*}{ UVB (280-320 nm) } & \multirow[b]{2}{*}{ UVA (320-400 nm) } & \multirow[b]{2}{*}{ Visible (400-700 nm) } \\
\hline & Site classification $^{\mathrm{a}}$ & $n^{\mathrm{b}}$ & & & \\
\hline \multirow[t]{3}{*}{ April 15, 2003} & Glacial & 2 & $0.906^{\mathrm{c}}, 1.04^{\mathrm{c}}$ & $0.482,0.547$ & $0.339^{c}, 0.408^{c}$ \\
\hline & Port Valdez & 2 & $0.983^{\mathrm{c}}, 1.05^{\mathrm{c}}$ & $0.782,0.786$ & $0.474^{\mathrm{c}}, 0.548^{\mathrm{c}}$ \\
\hline & $\mathrm{PWS}^{\mathrm{d}}$ & 4 & $0.878-1.02^{\mathrm{c}}$ & $0.445-0.656^{\mathrm{d}}$ & $0.254-0.535^{\mathrm{c}}$ \\
\hline \multirow[t]{3}{*}{ June 24, 2003} & Glacial & 2 & $6.84,9.14$ & $3.83,10.6$ & $2.00,10.2$ \\
\hline & Port Valdez & 3 & $1.65-1.93$ & $0.742-0.843$ & $0.460-0.490$ \\
\hline & $\mathrm{PWS}^{\mathrm{f}}$ & 10 & $0.676-1.11$ & $0.330-0.492$ & $0.161-0.243$ \\
\hline \multirow[t]{3}{*}{ September 12, 2003} & Glacial & 2 & $2.57,>1^{\mathrm{e}}$ & $2.11,>1^{\mathrm{e}}$ & $1.41,>1^{\mathrm{e}}$ \\
\hline & Port Valdez & 3 & $1.45-1.79$ & $0.821-0.882$ & $0.448-0.536$ \\
\hline & PWS & 2 & $0.844,0.966$ & $0.464,0.471$ & $0.177,0.203$ \\
\hline \multirow[t]{3}{*}{ April 15, 2004} & Glacial & 2 & $1.00,1.07$ & $0.706,0.730$ & $0.466,0.496$ \\
\hline & Port Valdez & 3 & $0.852-1.19$ & $0.674-0.874$ & $0.449-0.590$ \\
\hline & PWS & 2 & $1.09-1.82$ & $0.724,0.917$ & $0.482,0.508$ \\
\hline \multirow[t]{3}{*}{ June 24, 2004} & Glacial & 2 & $>1^{\mathrm{e}},>1^{\mathrm{e}}$ & $>1^{\mathrm{e}},>1^{\mathrm{e}}$ & $>1^{\mathrm{e}},>1^{\mathrm{e}}$ \\
\hline & Port Valdez & 3 & $2.52-2.74$ & $1.75-3.52$ & $0.765-1.74$ \\
\hline & PWS & 2 & $0.770,0.833$ & $0.463,0.549$ & $0.206,0.285$ \\
\hline \multirow[t]{3}{*}{ September 24, 2004} & Glacial & 1 & 1.67 & 0.632 & $<1^{\mathrm{e}}$ \\
\hline & Port Valdez & 1 & 1.40 & 0.759 & 0.430 \\
\hline & PWS & 1 & 1.23 & 0.592 & $<1^{\mathrm{e}}$ \\
\hline \multirow[t]{3}{*}{ January 2, 2005} & Glacial & 1 & 0.311 & 0.416 & 0.230 \\
\hline & Port Valdez & 3 & $0.380-0.571$ & $0.391-0.417$ & $0.220-0.240$ \\
\hline & PWS & 1 & 0.371 & 0.316 & 0.172 \\
\hline \multirow[t]{3}{*}{ April 27, 2005} & Glacial & 2 & $>1^{\mathrm{e}},>1^{\mathrm{e}}$ & $0.500,0.551$ & $0.291,0.340$ \\
\hline & Port Valdez & 3 & $>1^{\mathrm{e}},>1^{\mathrm{e}}$ & $0.473-0.595$ & $0.260-0.331$ \\
\hline & PWS & 2 & $>1^{\mathrm{e}},>1^{\mathrm{e}}$ & $0.476,0.502$ & $0.253-0.275$ \\
\hline \multirow[t]{3}{*}{ June 23, 2005} & Glacial & 2 & $3.35,>1^{\mathrm{e}}$ & $2.55,3.67$ & $1.07,1.30$ \\
\hline & Port Valdez & 3 & $1.39-1.78$ & $0.891-1.60$ & $0.516-0.830$ \\
\hline & PWS & 2 & $0.864-0.964$ & $0.526,0.555$ & $0.248,0.272$ \\
\hline \multirow[t]{3}{*}{ September 19, 2005} & Glacial & 2 & $3.04,3.24$ & $1.20,1.27$ & $0.690,0.716$ \\
\hline & Port Valdez & 3 & $1.75-1.89$ & $0.879-0.953$ & $0.505-0.568$ \\
\hline & PWS & 2 & $1.22,1.23$ & $0.586,0.615$ & $0.254,0.301$ \\
\hline
\end{tabular}

a Glacial: locations near Lowe River and Glacial Stream; Port Valdez: locations near Mineral Creek, Gold Creek, and Shoup Bay; PWS: Bligh Reef and Outer Jack Bay. See Table 1.

${ }^{\mathrm{b}} n=$ number of sites monitored with Kd determined with $r^{2} \geq 0.9$.

c April 2003 UVB measurement determined at $305 \mathrm{~nm}$, and visible light measurement determined as photosynthetically active radiation.

${ }^{d}$ PWS also includes: measurements in central PWS (see Fig. 1) at $430 \mathrm{~m}$ depth (N 60 42.118; W 146 51.070$)$, and $450 \mathrm{~m}$ depth (N 60 35.266; W $146^{\circ}$ 50.144); UVA Kd at these sites determined at $380 \mathrm{~nm}$.

${ }^{\text {e }} K_{\mathrm{d}}$ value could not be accurately determined at station.

${ }^{\mathrm{f}}$ PWS: sites distant from glacial influences; see Barron and Barron [13]. 
Monitoring locations more than $100 \mathrm{~m}$ from shore were selected to represent water clarity in a general area rather than only localized conditions. Additional solar radiation measurements were performed in April 2003 with a Biospherical PUV2500 profiling radiometer (Biospherical Instruments, San Diego, CA, USA) to allow comparison to simultaneous measurements of UVA with the BWR and to allow water-column profiling at deep-water sites with rough seas. The profiling radiometer quantified irradiance at specific wavelengths (305, 320,340 , and $380 \mathrm{~nm}$ ) and photosynthetically active radiation. Salinity, temperature, and conductivity were profiled using a YSI Model 30 Handheld Salinity, Conductivity, and Temperature System instrument (YSI Incorporated, Yellow Springs, $\mathrm{OH}$, USA) at depths between 0.1 and $8 \mathrm{~m}$ at selected times and locations.

\section{Data analysis}

The $K_{\mathrm{d}}$ values were determined from the slope of the regression of natural $\log$ irradiance of visible light, UVA, or $\mathrm{UVB}\left(\mathrm{W} / \mathrm{m}^{2}\right)$ versus measurement depth $(\mathrm{m})$ from two replicate measurements at each monitoring location. If needed to achieve a significant regression and high coefficient of determination $\left(r^{2} \geq 0.9\right)$, deeper depths were successively dropped from the data analysis until the regression $r^{2}$ improved to 0.9 or greater with a minimum of three measurement depths. The $1 \%$ attenuation depths $\left(Z_{1 \%}\right.$; loss of $99 \%$ of incident radiation) were calculated from $Z_{1 \%}=4.605 / K_{\mathrm{d}}$. Seasonal effects (month of sampling) on $K_{\mathrm{d}}$ values for the different site classifications (glacial, Port Valdez, and PWS) and light types (visible, UVA, and UVB) were tested using nested analysis of variance (ANOVA) [19]. The statistical analysis included three main factors (season, site class, and light region) and one nested factor (specific monitoring locations within each site class) and their interactions. Each year of sampling was treated as a replicate for a given location. Type III sums of squares were used because the sampling design was unbalanced. Analyses were run using the aov function in the statistical package $\mathrm{R}$ (http:// www.r-project.org).

\section{Risk analysis}

Risks of photo-enhanced toxicity in PWS were estimated as probability distributions of hazard quotients with@Risk software (Palisade, Newfield, NY, USA) using Latin hypercube sampling and 10,000 iterations. The probability of risks was estimated from the ratio of calculated UVA doses in PWS and UVA doses necessary to cause photo-enhanced toxicity in $\mathrm{Pa}$ cific herring larvae [6]. The UVA doses at specified depths were determined using a two-step procedure. In the first step, a daily surface UVA dose $\left(\mathrm{W} \cdot \mathrm{h} / \mathrm{m}^{2}\right)$ was calculated from the daily photoperiod $(\mathrm{h})$ and measured surface UVA $\left(\mathrm{W} / \mathrm{m}^{2}\right)$ in the city of Valdez by assuming that irradiance at time $t(i(t))$ was described by a modified sine function: $i(t)=$ (irradiance at solar noon $) \cdot \sin ^{2}(\pi t / \mathrm{h})$ [20]. Daily dose was then estimated by integration as the area under the curve: Dose $=0.5$.(irradiance at solar noon).(number of daylight hours). The estimated UVA doses were compared to values derived from hourly UVA irradiance obtained from SBDART [17]. Estimated surface UVA doses were highly correlated $(r=0.988, p<$ $0.00001)$ and within $2 \%$ of SBDART UVA dose values. The UVA doses were calculated from log-normal distributions of UVA ground-surface doses for four periods of three months each: March through May, June through August, September through November, and December through February. In the second step, daily UVA doses at specified depths in the water column were calculated from the surface UVA dose and location- and season-specific $K_{\mathrm{d}}$ : PWS dose $=0.9 \cdot$ (surface dose) $\cdot e^{-K_{\mathrm{d}} \cdot \text { depth }}$. The surface UVA dose entering the water column was set as $90 \%$ of the surface dose determined at Valdez to account for irradiance loss from water-surface reflectance (i.e., $10 \%$ reduction) [21,22]. A log-normal distribution of $K_{\mathrm{d}}$ values within each site grouping (glacial, Port Valdez, or PWS) (Fig. 1) was used to estimate seasonal water-column attenuation.

The probability of photo-enhanced toxicity risks was determined from the ratio of total UVA doses at water-column depths of $0.5,2$, and $4 \mathrm{~m}$ and a UVA toxicity benchmark dose of $22 \mathrm{~W} \cdot \mathrm{h} / \mathrm{m}^{2}$. This UVA dose was the lowest UVA level that caused $50 \%$ mortality in herring larvae exposed to sunlight following an initial static exposure to $2.6 \mu \mathrm{g} / \mathrm{L}$ of total PAHs and a subsequent 8 -d observation period [6]. The exposure in this treatment declined rapidly with time and was estimated to be $1.1 \mu \mathrm{g} / \mathrm{L}$ of total PAHs at $2 \mathrm{~d}$ after initiation of the static exposure and $0.67 \mu \mathrm{g} / \mathrm{L}$ after $3 \mathrm{~d}$ [6]. Implicit assumptions in the risk analysis were that organisms would be exposed to water-column UVA for $2 \mathrm{~d}$ either concurrently with or following oil exposure, which was consistent with the herring larvae toxicity tests used in deriving the UVA benchmark [6], and that total PAH exposures would exceed $1 \mu \mathrm{g} / \mathrm{L}$.

\section{RESULTS}

\section{Surface solar irradiance}

Weekly measurements of solar radiation at the ground surface in the city of Valdez at approximately solar noon showed maximum irradiances of visible light, UVA, and UVB at each summer solstice and minimum values at each winter solstice in 2003, 2004, and 2005 (Fig. 2). In general, visible light surface irradiance was approximately 10-fold higher than UVA and 100-fold higher than UVB, with higher irradiance values under full-sun conditions relative to partly cloudy or full-cloud conditions (Fig. 2). The UVA ground-surface doses $\left(\mathrm{W} \cdot \mathrm{h} / \mathrm{m}^{2}\right.$; mean \pm standard deviation) varied with time over the periods of March through May (100 \pm 54.2$)$, June to August (124 \pm 63.2), September to November (31.6 \pm 35.0), and December to February $(10.4 \pm 10.2)$. Maximum measured values of solar radiation under conditions of $100 \%$ solar disk visibility and minimal clouds and haze generally were within $10 \%$ of atmospheric radiative transfer (SBDART) [17] modeled values (data not shown).

\section{Attenuation of downwelling solar radiation}

The natural log of solar irradiance and the measurement depths were highly correlated $\left(r^{2} \geq 0.9\right)$ to the maximum measurement depth of $8 \mathrm{~m}$ (Fig. 3) except in locations affected by glacial stream inputs and exhibiting water-column stratification (Fig. 4). Stratification of surface layers of lower-salinity, highly attenuating glacial flour were apparent from both water-quality and radiometric profiles (Fig. 4). Replicate measurements at each location exhibited less than $50 \%$ difference in irradiance measurements at equivalent depths, despite sometimes changing environmental conditions (e.g., cloud cover over solar disk). Differences in replicate irradiance measurements were a small source of variability compared to changes in irradiance because of water-column attenuation, which caused a 10-fold to greater than 100 -fold reduction in irradiance. At most locations and measurement periods, the $K_{\mathrm{d}}$ value determined for 


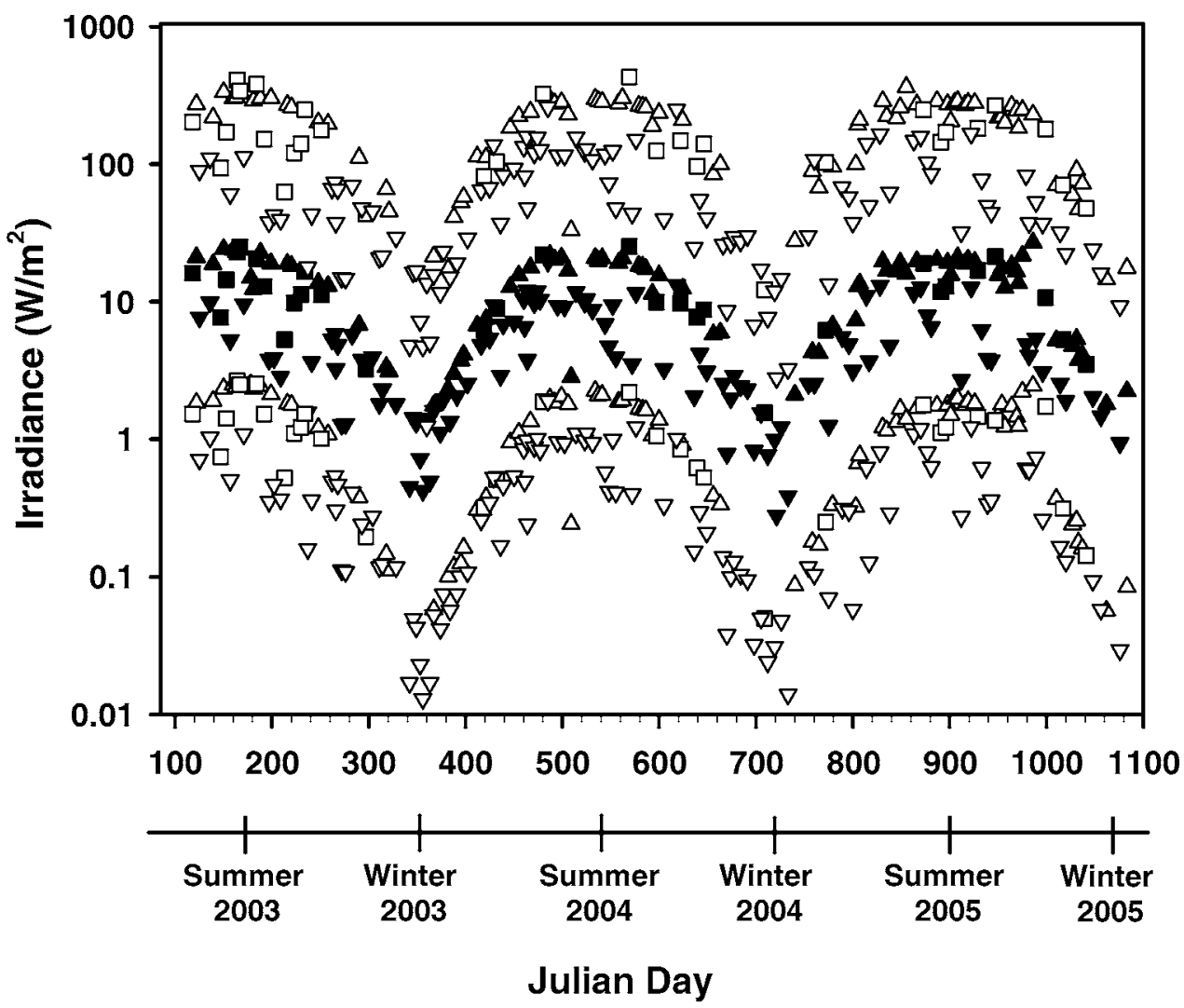

Fig. 2. Weekly measurements of surface solar radiation in Valdez, Alaska, USA $\left(61^{\circ} 07.37^{\prime} \mathrm{N}, 146^{\circ} 21.22^{\prime} \mathrm{W}\right)$ showing irradiance $\left(\mathrm{W} / \mathrm{m}^{2}\right)$ of visible light (upper white symbols), ultraviolet A (UVA; middle black symbols), and ultraviolet B (UVB; lower white symbols) radiation at approximately solar noon from April 15, 2003, to December, 19, 2005. General environmental conditions (visibility of solar disk) are shown by symbol shape: Full disk, upward triangle; partial disk, square; and no solar disk, downward triangle. Summer and winter solstices indicated on the bottom scale.

visible light was lower than the UVA $K_{\mathrm{d}}$, and the UVA $K_{\mathrm{d}}$ was lower than the UVB $K_{\mathrm{d}}$. The $K_{\mathrm{d}}$ values determined from broad wavelength measurements of UVA were within 5 to $20 \%$ of UVA wavelength-specific $K_{\mathrm{d}}$ values determined concurrently with a profiling radiometer.

\section{Temporal and spatial variation in $K_{d}$}

The attenuation of solar radiation varied from season to season and depended on distance from glacial influences (Fig. $5)$. The effect of season on $K_{\mathrm{d}}$ values depended significantly on the general sampling location (ANOVA, season $\times$ location: $d f=6, F=17.5, p<0.001$ ). The three site classes (glacial, Port Valdez, and PWS) had similar $K_{\mathrm{d}}$ values in winter and spring, whereas in summer and spring, the glacially affected locations had significantly higher $K_{\mathrm{d}}$ values (Table 2 and Fig. 5 ). The $K_{\mathrm{d}}$ values differed among light types (ANOVA: $d f=$ 2, $F=9.7, p<0.001$ ), but the effects of season and location on $K_{\mathrm{d}}$ values were consistent (i.e., no significant interactions with light type). The three site classes were well differentiated, and no significant differences were found in $K_{\mathrm{d}}$ values between specific locations within a site class (ANOVA: $d f=14, F=$ $0.49, p=0.937)$.

The $1 \%$ attenuation depths were affected by season and proximity to glacial inputs and ranged from 0.4 to $15 \mathrm{~m}$ (UVB and UVA) and from 0.5 to $28 \mathrm{~m}$ (visible light). In January, temperature $\left(<6^{\circ} \mathrm{C}\right)$, salinity $(\sim 30 \mathrm{ppt})$, and conductivity $(\sim 50$ $\mu \mathrm{mho} / \mathrm{cm}$ ) generally were uniform to $8 \mathrm{~m}$, and attenuation of solar radiation was log linear (Figs. 3 and 4). In April, stratification from a freshwater surface layer was apparent to a depth of approximately $1 \mathrm{~m}$ in locations affected by glacial meltwater from Lowe River and Glacial Stream, but $K_{\mathrm{d}}$ values remained log linear (Fig. 4). During winter and spring in PWS, only limited spatial variation was found in water-column attenuation of solar radiation, with relatively constant visible light, UVA, or UVB $K_{\mathrm{d}}$ values between Port Valdez and PWS (Fig. 5). In contrast, summer and fall $K \mathrm{~d}$ values generally exhibited a 10-fold range from highly attenuating locations affected by glacial streams to low $K_{\mathrm{d}}$ values distant from glacial influences (Table 2). Locations more distant from glacial influences exhibited less dramatic stratification and log-linear attenuation (Fig. 3). In contrast, locations in Port Valdez that were affected by glacial inputs showed stratification and high attenuation at shallow depths and less attenuation below the layer of glacial meltwater (Fig. 4). The spatial variation in $K_{\mathrm{d}}$ values determined in June and September were consistent with August 2003 satellite imagery (http://modis-snow-ice.gsfc. nasa.gov/082203ak.html) showing locations of high glacial flour and sediment.

\section{UVA dosimetry and photo-enhanced toxicity risks}

The UVA surface doses followed general trends as groundsurface irradiances, but seasonal differences were substantially greater because of large changes in day length at the subarctic latitude of Valdez (Fig. 6). Surface doses of UVA exceeded the UVA phototoxicity benchmark dose $70 \%$ of the time over the entire 2.5-year monitoring period. The probability of UVAbased photo-enhanced toxicity risks estimated from UVA dosimetry within the water-column decreased with increasing depth (Fig. 7). In spring, a 46 to $97 \%$ probability of UVAbased risks was found at depths between 0.5 and $2 \mathrm{~m}$ in all 

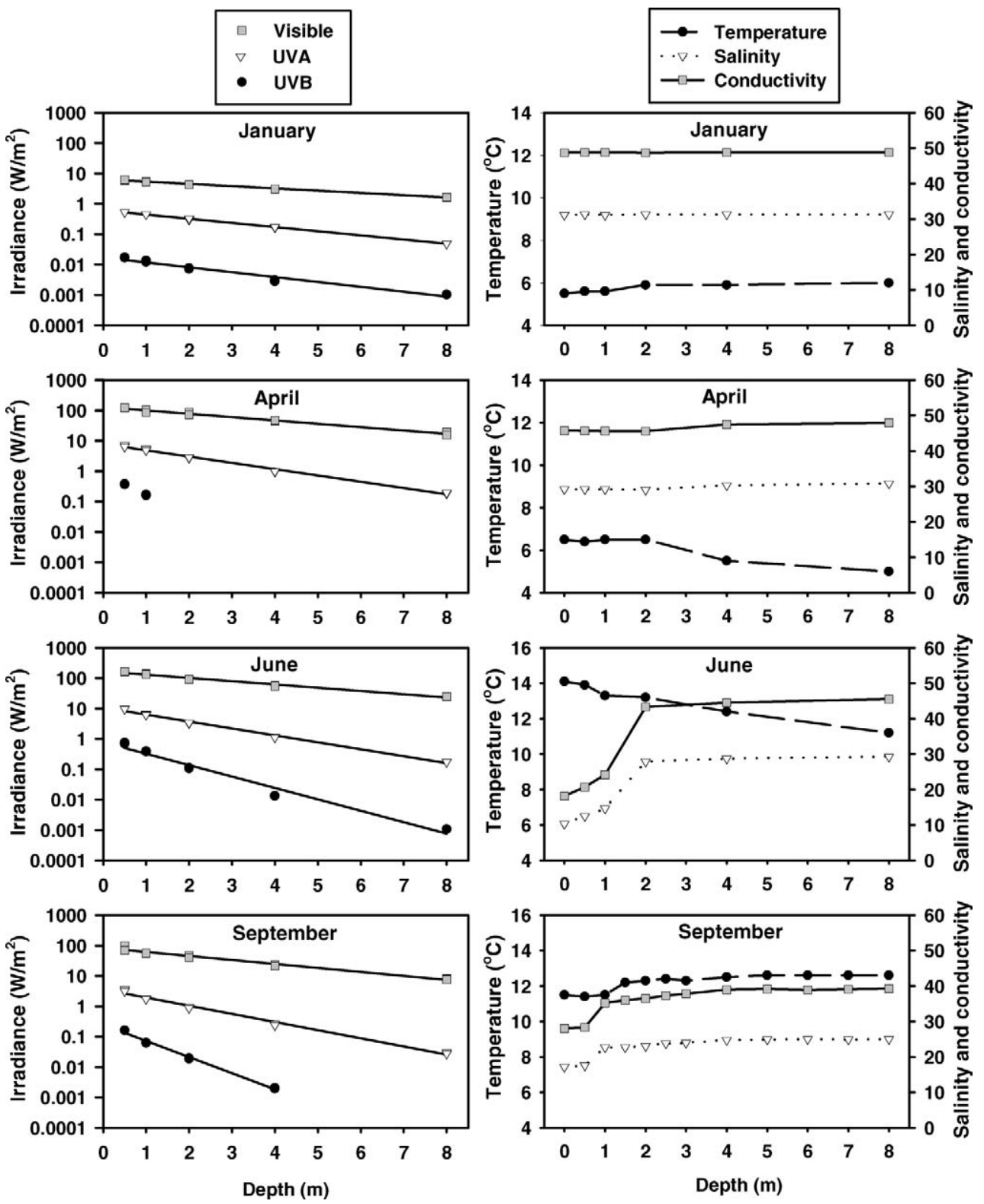

Fig. 3. Seasonal attenuation of solar radiation and depth profiles of temperature, salinity, and conductivity in Jack Bay, Prince William Sound, Alaska, USA, during 2005. Data are from two replicate measurements. Solar radiation data are plotted on common log coordinates for observation; downwelling diffuse attenuation coefficients $\left(K_{\mathrm{d}}\right)$ were calculated using natural log-transformed irradiances.

monitoring locations, including areas near glacial streams (Fig. 7). In summer, the probability of photo-enhanced toxicity risks varied with location. Open-sea and bay areas of PWS had a greater than $90 \%$ probability of risks at $2 \mathrm{~m}$ and $35 \%$ at $4 \mathrm{~m}$, whereas glacially affected areas had a low probability of risks (Fig. 7). All locations had relatively low probabilities of risks in both fall and winter (Fig. 7).

\section{DISCUSSION}

Solar radiation is an important determinant of primary production and can influence species distributions and population survival in marine ecosystems $[23,24]$. Solar radiation in subarctic environments, however, has received very limited characterization relative to measurements in the Arctic and Antarctic systems [13]. A 2.5-year record of weekly measurements of ground-surface solar radiation in Valdez followed expected trends of maximum solar irradiance at each summer solstice and minimum values at each winter solstice. The frequent 10fold reductions in weekly maximum clear-sky surface irradiances was attributed to large variations in environmental conditions over the 142-week monitoring period. Computed daily ground-surface doses of UV demonstrated the potential for high UV doses in subarctic environments despite often inclement weather, with $31 \%$ of weekly UVA doses exceeding $100 \mathrm{~W} \cdot \mathrm{h} / \mathrm{m}^{2}$ and $13 \%$ of weekly UVB doses exceeding 15 $\mathrm{W} \cdot \mathrm{h} / \mathrm{m}^{2}$. These surface solar radiation measurements may have importance in evaluating long-term changes in UV, which is expected to increase with losses of stratospheric ozone [24]. Additionally, although UVA is considered to be the primary region of the solar spectrum responsible for photo-enhanced toxicity, UVB likely influences photo-enhanced toxicity risks of both pyrogenic and petrogenic PAHs $[1,6]$.

Seasonal and spatial variation in $K_{\mathrm{d}}$ values was influenced by two macroscale processes in PWS: The spring plankton 

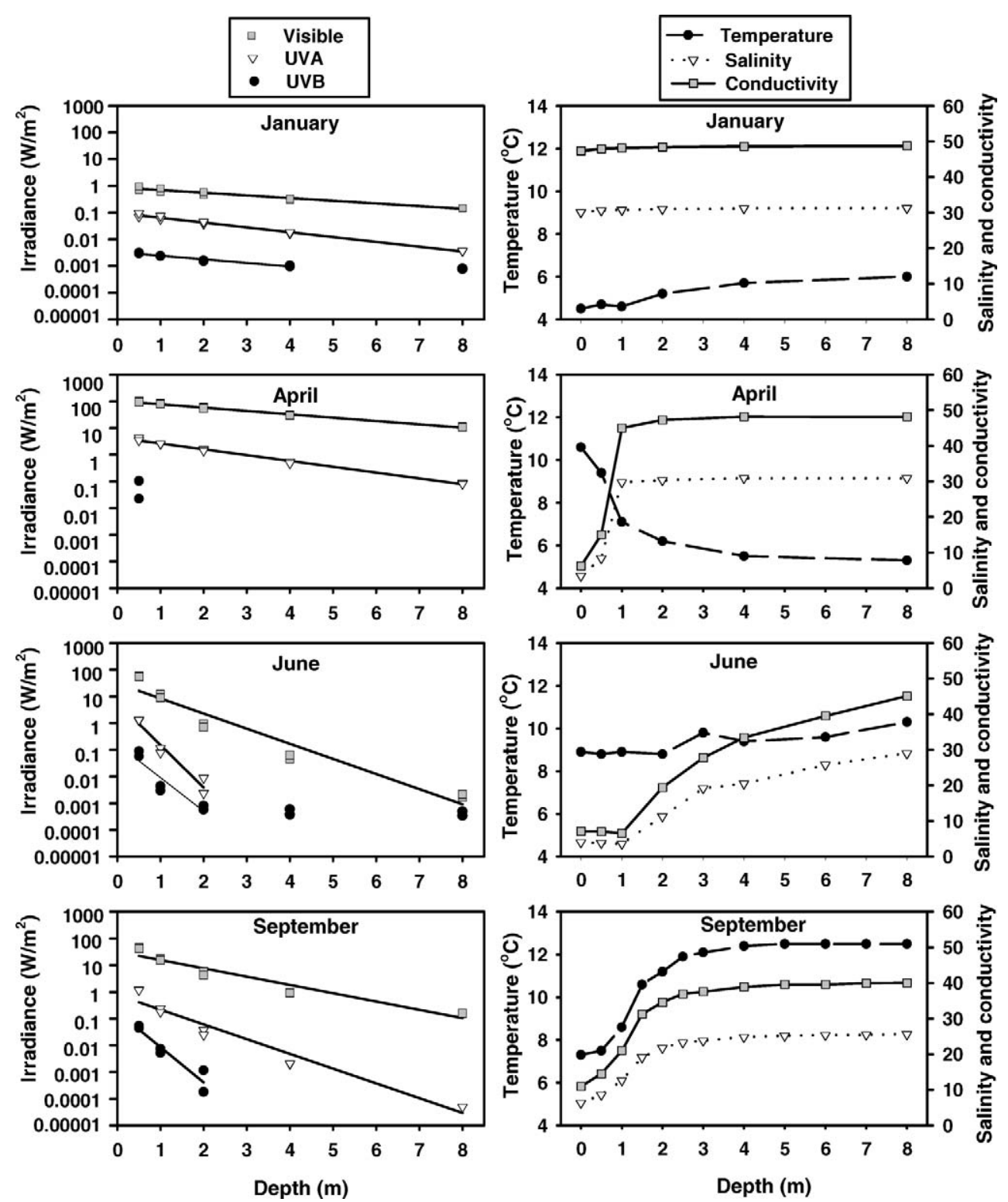

Fig. 4. Seasonal attenuation of solar radiation and depth profiles of temperature, salinity, and conductivity in Port Valdez, Alaska, USA, affected by the glacial stream Lowe River during 2005. Data are from two replicate measurements. Solar irradiances are plotted on common log coordinates for observation; downwelling diffuse attenuation coefficients $\left(K_{\mathrm{d}}\right)$ were calculated using natural log-transformed irradiances.

bloom, which historically has peaked in mid-April [18], and an influx in glacial meltwater and flour, which typically begins in May and results in water-column stratification [13,25]. Measurements made at different times of year and times of day resulted in changes in solar zenith angle, but the effect on $K_{\mathrm{d}}$ was expected to be minimal for wavelengths below $510 \mathrm{~nm}$ [26]. Thus, the UVA and UVB $K_{\mathrm{d}}$ values determined in the present study during different times and seasons were considered to be sufficiently comparable. The $1 \%$ attenuation depths ranged from 0.4 to $15 \mathrm{~m}$ (UVB and UVA) and from 0.5 to 28 $\mathrm{m}$ (visible light) and were within the range reported for a diversity of estuarine and marine systems [23,27]. Whereas solar irradiance can change rapidly with changing environmental conditions (e.g., cloud cover), the optical properties of water are more constant and are determined primarily by seasonal influences on a macroscale [13]. The extent and magnitude of spatial and temporal variation in solar irradiance and attenuation have important implications in assessing risks of phototoxic chemicals, because they will affect the spatial and vertical distribution and the potential exposure of ecological receptors. Projected changes in climate and UV also will have heterogeneous impacts on potential phototoxicity risks in subarctic and other environments because of effects on water clarity, water quality, mixing, and stratification $[6,24]$.

The present study provides, to our knowledge, the first quantitative assessment of photo-enhanced toxicity risks of spilled oil in the water column of PWS, a subarctic sea in southcentral Alaska. The photo-enhanced toxicity of petroleum and chemically dispersed oil has been of concern in PWS because of the risks of oil spills from daily tanker shipments of ANS, the known high phototoxicity of ANS [6,12], and the potential use of chemical dispersants as an oil-spill countermeasure. For example, more than 1 million $\mathrm{kg}$ of PAHs and heterocycles have been transported through PWS each day as constituents of crude oil shipped from the Valdez Marine Terminal in Port Valdez, based on measurements of hydrocarbon 

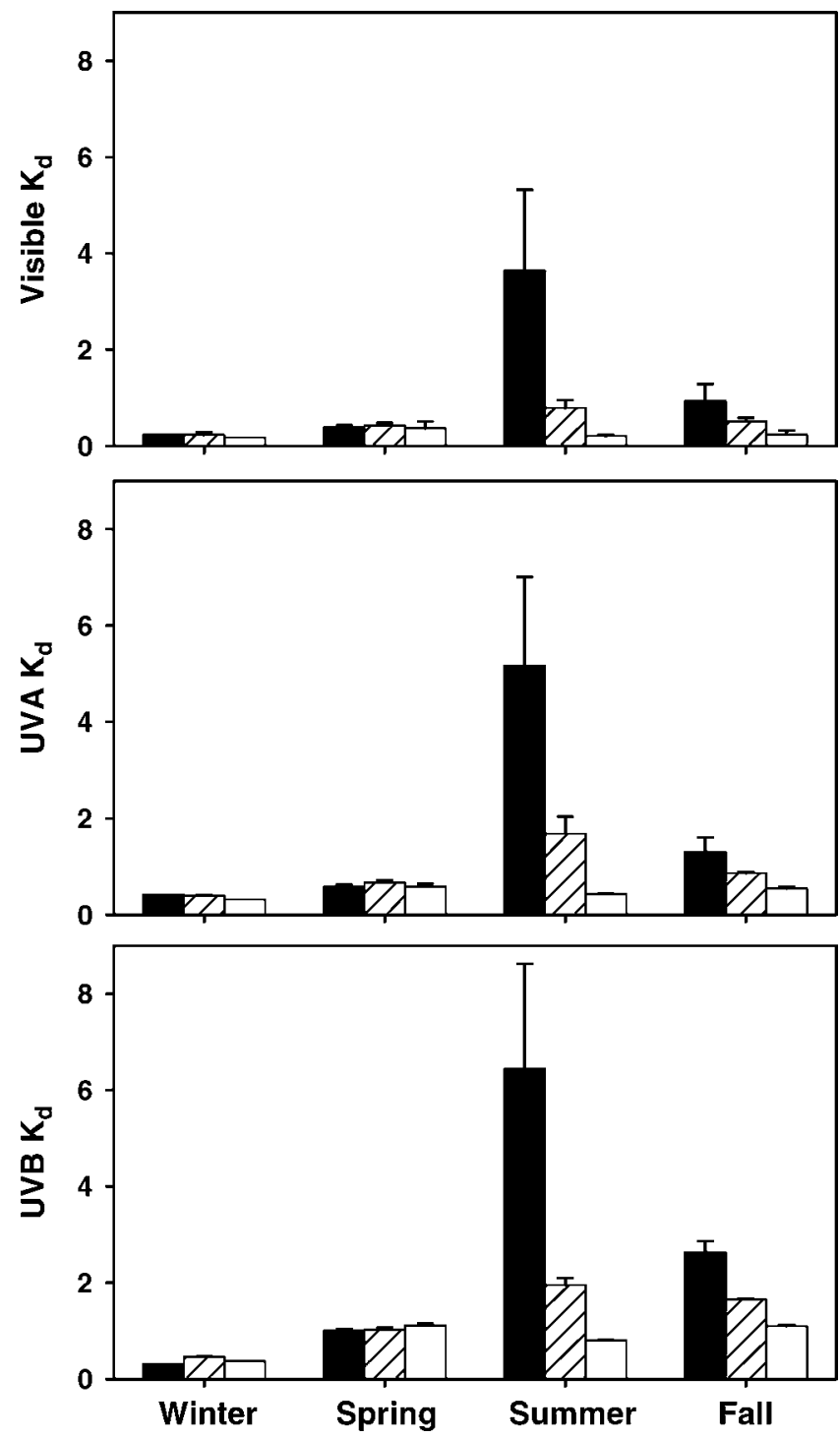

Fig. 5. Seasonal diffuse attenuation coefficients $\left(K_{\mathrm{d}} ; 1 / \mathrm{m}\right.$; mean \pm standard deviation) for ultraviolet A (UVA), ultraviolet B (UVB), and visible light solar radiation in three areas of Prince William Sound (PWS), Alaska, USA. Locations affected by glacial streams (ם); Port Valdez $(\square)$, and PWS areas outside of Port Valdez $(\square)$ are shown.

concentrations and shipment volumes [28]. Previous studies have considered oil-spill risks in PWS, but to our knowledge, phototoxicity has not been considered in the assessment of current risks or impacts from spilled oil [28]. A high probability of photo-enhanced toxicity was found in all areas during the spring to depths of $2 \mathrm{~m}$, which is the period of herring spawning and larval emergence in PWS. Phototoxicity risks decreased with water depth at all locations because of UVA attenuation, and risks at a depth of $4 \mathrm{~m}$ were probable $(36 \%)$ only during the summer in PWS because of long photoperiods and limited glacial influences in the open water and bays of PWS. In general, Arctic and subarctic regions experience less irradiance than lower latitudes but have high solar radiation doses during periods of long day length. Fall had a low probability of risks because of generally lower water clarity and decreasing day length, and risks were unlikely during winter because of very short photoperiods.

The results of this screening-level risk analysis were considered to have both high confidence and high ecological rel-

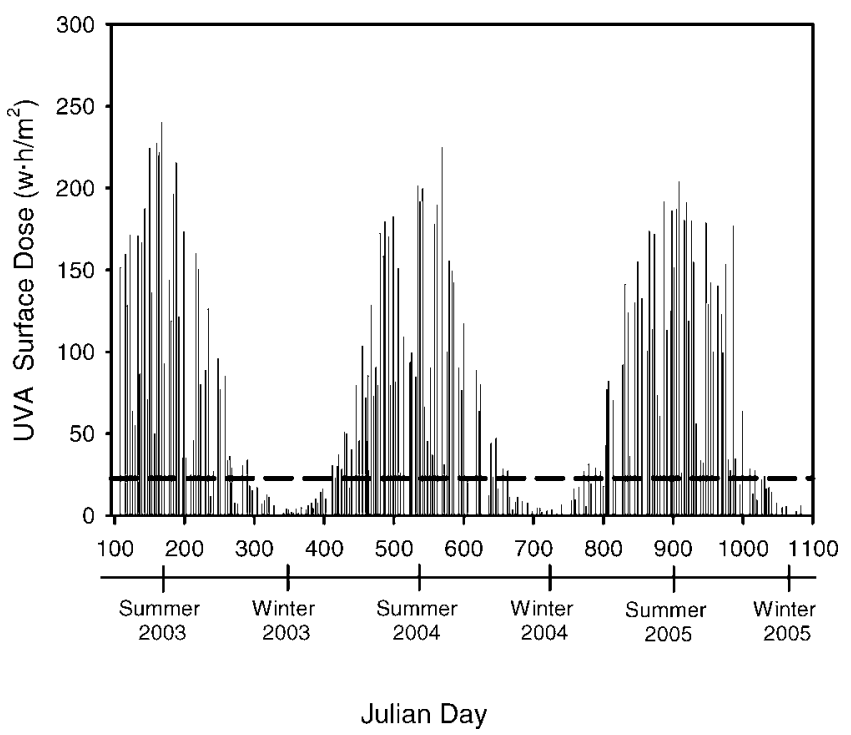

Fig. 6. Daily surface ultraviolet A (UVA) dose $\left(\mathrm{W} \cdot \mathrm{h} / \mathrm{m}^{2}\right)$ calculated from day length $(\mathrm{h})$ and measured UVA $\left(\mathrm{W} / \mathrm{m}^{2}\right)$ in the City of Valdez, Alaska, USA. The dashed line provides comparison of the UVA phototoxicity benchmark of $22 \mathrm{~W} \cdot \mathrm{h} / \mathrm{m}^{2}$ [6] to UVA surface doses.

evance because of site-specific measures of solar radiation and species-specific measurements of toxicity. Risk estimates were based on UVA levels, because UVA has been considered to be the primary spectral component of solar radiation that enhances phototoxicity [1]. The UVA exposures were estimated from seasonal and spatial assessments of water-column attenuation and measured surface solar radiation in the City of Valdez, which was considered to represent the variation in PWS meteorological conditions. A probabilistic assessment incorporated the variability and uncertainty in UVA exposure to aquatic organisms because of location, depth, and season. The UVA phototoxicity dose was determined in larvae spawned from field-collected herring in Alaska and tested under conditions of water quality, clarity, and natural sunlight representative of PWS that included visible light, UVA, and UVB exposure [6]. Dissolved organic carbon was not measured in the present study, but the phototoxicity benchmark was derived from laboratory studies using southeastern Alaska bay water filtered through a $1-\mu \mathrm{m}$ nesh (large enough to pass dissolved organic material and microzooplankton). Also, the comparability of estimated water-column UVA doses and the phototoxicity dose was considered to be high, because both were determined with the same optics and instrumentation (Macam 203 BWR). Thus, any bias or inaccuracies in instrument optics should be similar in both UV monitoring and phototoxicity studies. Pacific herring larvae were considered to have high ecological relevance for this assessment, because the distribution in PWS encompassed many of the UV monitoring sites used in this assessment. As noted by Stevenson [14], McGurk and Brown [15], and Norcross et al. [16], larval herring are pelagic planktivores feeding on zooplankton in the photic zone, typically in the upper $2 \mathrm{~m}$ of surface water and within $2 \mathrm{~km}$ of shore. This life stage is not free-swimming, and larval herring are carried rapidly by tidal currents away from intertidal areas into open-water bays [14-16].

The risk analysis was predicated on a petrogenic PAH exposure of greater than $1 \mu \mathrm{g} / \mathrm{L}$ of total PAHs $(0.5 \mu \mathrm{g} / \mathrm{g})$ and sunlight exposure with $22 \mathrm{~W} \cdot \mathrm{h} / \mathrm{m}^{2}$ of UVA over a 2 -d period, as determined from Barron et al. [6]. In comparison, total PAH 

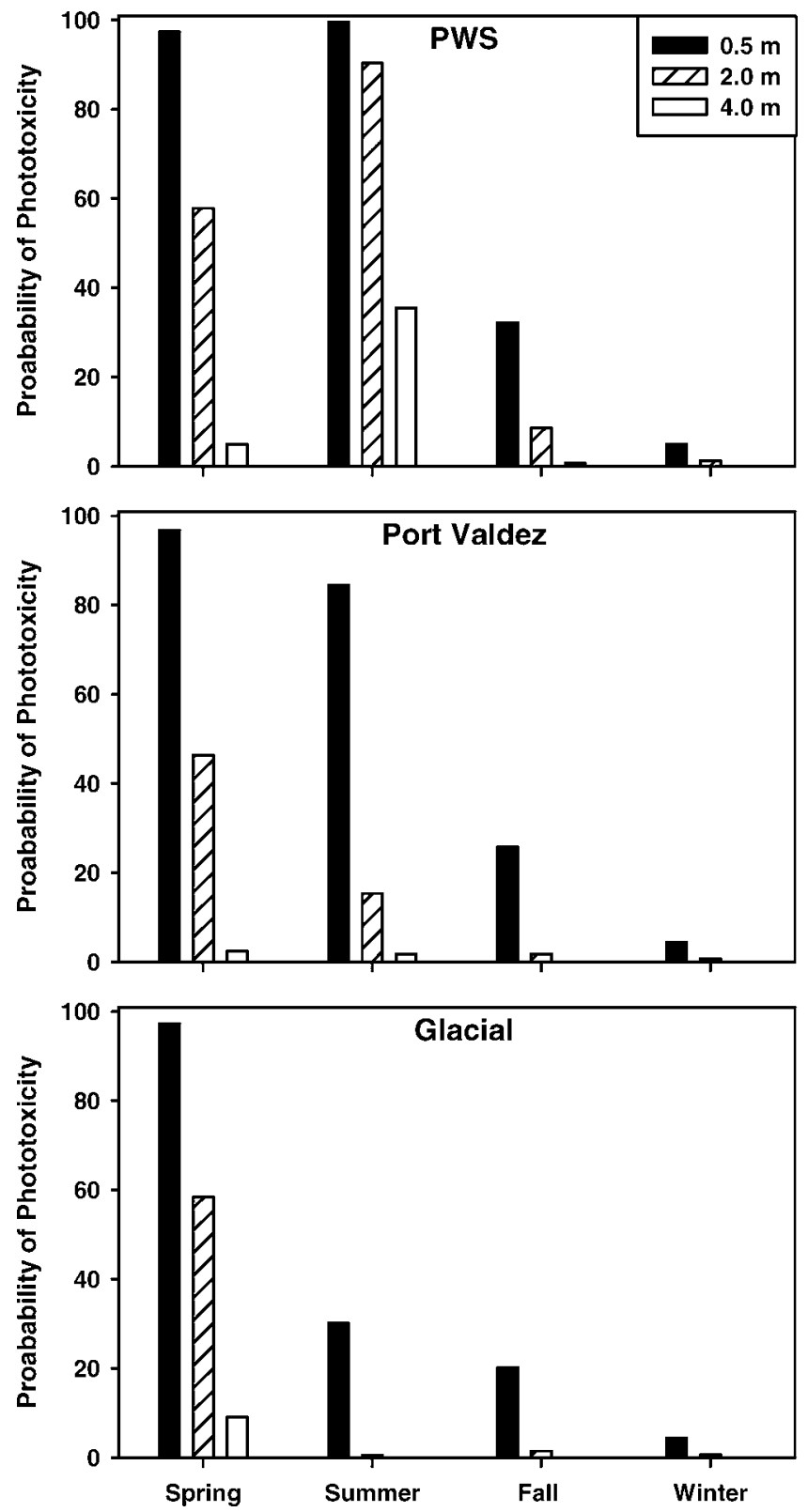

Fig. 7. Probability of photo-enhanced toxicity in Prince William Sound (PWS), Port Valdez, and glacially affected areas of Port Valdez (glacial) Alaska, USA, during spring, summer, fall, and winter seasons. Risk estimates were derived from ultraviolet A (UVA) doses at depths of $0.5,2$, and $4 \mathrm{~m}$ and a UVA phototoxicity benchmark dose of 22 $\mathrm{W} \cdot \mathrm{h} / \mathrm{m}^{2}$ determined from Barron et al. [6].

concentrations in water samples collected from the path of the Exxon Valdez oil spill during the first year of that spill ranged from nondetectable to $42 \mu \mathrm{g} / \mathrm{L}$ and averaged $0.4 \mu \mathrm{g} / \mathrm{L}$ [29]. For several weeks after the spill, total PAH concentrations greater than $1 \mu \mathrm{g} / \mathrm{L}$ persisted in the water column in several PWS bays that provided herring spawning habitat, including Snug Harbor, Herring Bay, and Northwest Bay [30,31]. Neff and Stubblefield [32] reported that total PAH concentrations exceeded $1 \mu \mathrm{g} / \mathrm{L}$ in $17 \%$ of open-water samples. Higher PAH exposures would result in an increased risk, whereas lower $\mathrm{PAH}$ exposures would decrease the probability of photoenhanced toxicity.

These results demonstrate substantial temporal and spatial variation in solar radiation in PWS and the potential for sig- nificant photo-enhanced toxicity risks from spilled oil based on an assessment of UVA dosimetry and UVA toxicity benchmarks. Research also suggests that UVB may be a factor in the photo-enhanced toxicity of weathered ANS, and the photoenhanced toxicity benchmarks were developed with concurrent UVB and visible light exposures in herring larvae [6]. Phototoxicity risks would be higher for species that are more sensitive than herring larvae and for longer UV exposures, and risks would be lower for less sensitive species and shorter exposures. Species and life stages that would be at risk from photo-enhanced toxicity in PWS are those most likely to be exposed to both spilled oil and UV. This may include important marine fish stocks that produce pelagic eggs and larvae [3] as well as pelagic larvae of bivalves that can transfer phototoxic PAHs to their offspring $[2,33]$. Other species at risk include zooplankton that inhabit the photic zone, including calanoid copepods that can exhibit high PAH bioaccumulation [12]. Herring are at high risk because of the high sensitivity of larvae to the photo-enhanced toxicity of both weathered oil and chemically dispersed oil as well as their life history as intertidal spawners and pelagic planktivores [6,14-16]. These results demonstrate substantial temporal and spatial variation in solar radiation in PWS and the potential for significant photoenhanced toxicity risks from spilled oil to sensitive species and life stages. Other species and life stages, such as salmon, may be at less risk from photo-enhanced toxicity [11].

Acknowledgement-Thanks to the PWS Regional Citizens Advisory Council for technical assistance, including Tony Parkin, Dan Gilson, Lisa Ka'aihue, and Rhonda Arvidson, and thanks to John Weinstein for review of a draft of this manuscript. Thanks also to Dave Janka and Auklet Charter Services for vessel support during seasonal monitoring events and to the Ship Escort/Response Vessel System vessel Krystal Sea and its crew for vessel support during the spring 2003 monitoring event. This research was funded in part by PWS Regional Citizens Advisory Council through a contract to P.E.A.K. Research during 2003.

\section{REFERENCES}

1. Diamond SA, Mount DR, Mattson VR, Heinis LJ, Highland TL, Adams AD, Simcik MF. 2006. Photoactivated polycyclic aromatic hydrocarbon toxicity in medaka (Oryzias latipes) embryos: Relevance to environmental risk in contaminated sites. Environ Toxicol Chem 25:3015-3023.

2. Barron MG. 2007. Sediment-associated phototoxicity to aquatic organisms. Hum Ecol Risk Assess 13:317-321.

3. Hunter JR, Kaupp SE, Taylor JH. 1982. Assessment of effects of UV radiation on marine fish larvae. In Calkins J, ed, The Role of Solar Radiation in Marine Ecosystems. Plenum, New York, NY, USA, pp 459-497.

4. Landrum PF, Giesy JP, Oris JT, Allred PM. 1987. Photoinduced toxicity of polycyclic aromatic hydrocarbons to aquatic organisms. In Vandermeulen JH, Hrudey SE, eds, Oil in Freshwater. Pergamon, New York, NY, USA, pp 304-318.

5. Barron MG, Ka'aihue L. 2001. Potential for photo-enhanced toxicity of spilled oil in Prince William Sound and Gulf of Alaska waters. Mar Pollut Bull 43:86-92.

6. Barron MG, Carls MG, Short JW, Rice SD. 2003. Photo-enhanced toxicity of aqueous phase and chemically dispersed weathered Alaska North Slope crude oil to Pacific herring eggs and larvae. Environ Toxicol Chem 22:650-660.

7. Pelletier MC, Burgess RM, Ho KT, Kuhn A, McKinney RA, Ryba SA. 1997. Phototoxicity of individual polycyclic aromatic hydrocarbons and petroleum to marine invertebrate larvae and juveniles. Environ Toxicol Chem 16:2190-2199.

8. Calfee RD, Little EE, Cleveland L, Barron MG. 1999. Photoenhanced toxicity of a weathered oil to Ceriodaphnia dubia reproduction. Environ Sci Pollut Res 6:207-212.

9. Cleveland L, Little EE, Calfee RD, Barron MG. 2000. Photoenhanced toxicity of a weathered oil to Mysidopsis bahia. Aquat Toxicol 49:63-76. 
10. Little EE, Cleveland L, Calfee R, Barron MG. 2000. Assessment of the photo-enhanced toxicity of a weathered oil to the tidewater silverside. Environ Toxicol Chem 19:926-932.

11. Barron MG, Carls MG, Short JW, Heintz R, Rice SD. 2005. Assessment of the phototoxicity of weathered Alaska North Slope crude oil to juvenile pink salmon. Chemosphere 60:105-110.

12. Duesterloh S, Short J, Barron MG. 2002. Photoenhanced toxicity of weathered Alaska North Slope crude oil to two species of marine calanoid zooplankton. Environ Sci Technol 36:39533959.

13. Barron MG, Barron KJ. 2005. Glacial influences on solar radiation in a subarctic sea. Photochem Photobiol 81:187-189.

14. Stevenson JC. 1962. Distribution and survival of herring larvae (Clupea pallasi Valenciennes) in British Columbia waters. J Fish Res Board Can 19:735-796.

15. McGurk MD, Brown ED. 1996. Egg-larval mortality of Pacific herring in Prince William Sound, Alaska, after the Exxon Valdez oil spill. Can J Fish Aquat Sci 53:2343-2354.

16. Norcross BL, Brown ED, Foy RJ, Frandsen M, Gay SM, Kline TC, Mason DM, Patrick EV, Paul AJ, Stokesbury KDE. 2001. A synthesis of the life history and ecology of juvenile Pacific herring in Prince William Sound, Alaska. Fish Oceanogr 10(Suppl. 1): 42-57.

17. Ricchiazzi P, Yang S, Gautier C, Sowle D. 1998. SBDART: A research and teaching software tool for plane-parallel radiative transfer in the Earth's atmosphere. Bull Am Meteorol Soc 79: 2110-2114.

18. Eslinger DL, Cooney RT, Mcroy CP, Ward A, Kline TC, Simpson EP, Wang J, Allen JR. 2001. Plankton dynamics: Observed and modeled responses to physical conditions in Prince William Sound, Alaska. Fish Oceanogr 10:81-96.

19. Sokal RR, Rohlf FJ. 1995. Biometry, 3rd ed. W. H. Freeman, New York, NY, USA.

20. Veen A. 1996. A continuous culture system for the study of UV-B effects on microalgae. Scientia Marina 60(Suppl. 1):89-93.

21. Jerome JH, Bukata RP. 1998. Tracking the propagation of solar ultraviolet radiation: Dispersal of ultraviolet photons in inland waters. J Gt Lakes Res 24:666-680.

22. Jerlov NG. 1976. Marine Optics. Elsevier Oceanography Series 14. Elsevier, Amsterdam, The Netherlands.

23. Browman HI. 2003. Assessing the impacts of solar ultraviolet radiation on the early life stages of crustacean zooplankton and ichthyoplankton in marine coastal systems. Estuaries 26:30-39.

24. Weatherhead EC, Morseth CM. 1998. Climate change, ozone, ultraviolet radiation and effects in the Arctic. Chapter 11. AMAP Assessment Report: Arctic Pollution Issues. Arctic Monitoring and Assessment Programme, Oslo, Norway, pp 717-774.

25. Alexander V, Chapman T. 1980. Phytotoxicity. In Colonell JM, ed, Port Valdez, Alaska: Environmental Studies 1976-1979. Institute of Marine Science, University of Alaska, Fairbanks, pp 125-142.

26. Zheng X, Dickey T, Chang G. 2002. Variability of the downwelling diffuse attenuation coefficient with consideration of inelastic scattering. Applied Optics 41:6477-6488.

27. Barron MG, Little EE, Calfee RD, Diamond S. 2000. Quantifying solar spectral irradiance in aquatic habitats for the assessment of photo-enhanced toxicity. Environ Toxicol Chem 19:920-925.

28. Merrick JRW, van Dorp JR, Mazzuchi TA, Harrald JR, Spahn JE, Grabowski MR. 2002. The Prince William Sound risk assessment. Interfaces 32:25-40.

29. Boehm PD, Neff JM, Page DS. 2007. Assessment of polycyclic aromatic hydrocarbon exposure in the waters of Prince William Sound after the Exxon Valdez oil spill: 1989-2005. Mar Pollut Bull 54:339-367.

30. Neff JM, Burns WA. 1996. Estimation of polycyclic aromatic hydrocarbon concentrations in the water column based on tissue residues in mussels and salmon: An equilibrium partitioning approach. Environ Toxicol Chem 15:2240-2253.

31. Short JW, Harris PM. 1996. Chemical sampling and analysis of petroleum hydrocarbons in near-surface seawater of Prince William Sound after the Exxon Valdez oil spill. In Rice SD, Spies RB, Wolfe DA, Wright BA, eds. Proceedings of the Exxon Valdez Oil Spill Symposium, Anchorage, Alaska. American Fisheries Society, Bethesda, MD, pp 17-28.

32. Neff JM, Stubblefield WA. 1995. Chemical and toxicological evaluation of water quality following the Exxon Valdez oil spill. In Wells PG, Butler JN, Hughes JS, eds, Exxon Valdez Oil Spill: Fate and Effects in Alaska Waters. STP 1219. American Society of Testing and Materials, Philadelphia, PA, pp 141-177.

33. Pelletier MC, Burgess RM, Cantwell MG, Serbst JR, Ho KT, Ryba SA. 2000. Importance of maternal transfer of the photoreactive polycyclic hydrocarbon fluoranthene from benthic adult bivalves to their pelagic larvae. Environ Toxicol Chem 19:26912698. 